\title{
Evolution of flower allometry and pigmentation in Mammillaria haageana (Cactaceae)
}

\author{
Ulises Rosas ${ }^{1 *}\left(\mathbb{D}\right.$, Elisa Sofía Fuentes-Pérez ${ }^{1}$, Cristian R. Cervantes ${ }^{1,2} \mathbb{B}$, Estela Sandoval-Zapotitla ${ }^{1}$, \\ Itzel Santiago-Sandoval', Salvador Arias ${ }^{1}$ (1) and Jerónimo Reyes-Santiago ${ }^{1}$ (B)
}

\begin{abstract}
Background: A puzzle in evolution is the understanding of how the environment might drive subtle phenotypic variation, and whether this variation is adaptive. Under the neutral evolutionary theory, subtle phenotypes are almost neutral with little adaptive value. To test this idea, we studied the infraspecific variation in flower shape and color in Mammillaria haageana, a species with a wide geographical distribution and phenotypic variation, which populations are often recognized as infraspecific taxa.
\end{abstract}

Results: We collected samples from wild populations, kept them in the greenhouse for at least one reproductive year, and collected newly formed flowers. Our first objective was to characterize tepal natural variation in M. haageana through geometric morphometric and multivariate pigmentation analyses. We used landmark-based morphometrics to quantify the trends of shape variation and tepal color-patterns in $20 \mathrm{M}$. haageana accessions, belonging to five subspecies, plus $8 \mathrm{M}$. albilanata accessions for comparison as the sister species. We obtained eight geometric morphometric traits for tepal shape and color-patterns. We found broad variation in these traits between accessions belonging to the same subspecies, without taxonomic congruence with those infraspecific units. Also the phenetic cluster analysis showed different grouping patterns among accessions. When we correlated these phenotypes to the environment, we also found that solar radiation might explain the variation in tepal shape and color, suggesting that subtle variation in flower phenotypes might be adaptive. Finally we present anatomical sections in $\mathrm{M}$. haageana subsp. san-angelensis to propose some of the underlying tepal structural features that may give rise to tepal variation.

Conclusions: Our geometric morphometric approach of flower shape and color allowed us to identify the main trends of variation in each accession and putative subspecies, but also allowed us to correlate these variation to the environment, and propose anatomical mechanisms underlying this diversity of flower phenotypes.

Keywords: Natural variation, Flower evolution, Cacti, Morphometrics, Cactoideae, Pigmentation, Tepal, Perianth

\section{Introduction}

The nature of phenotypic variation is a problem that perplexed generations of scientists, including Darwin

\footnotetext{
*Correspondence: urosas@ib.unam.mx

1 Jardín Botánico, Instituto de Biología, Universidad Nacional Autónoma de México, 04510 Mexico City, Mexico

Full list of author information is available at the end of the article
}

himself. Flower evolution has been adopted as a model to understand these bases of natural variation [1]. On the one hand, when discrete variation has been observed, for instance in flower color, it has been possible to associate it to the underlying biochemical pathways [2], or to selective genetic sweeps [3], or variation driven by the environment [4]. However, when the phenotypic variation is subtle, identifying its underlying bases is rather a difficult task. Based on what has been observed in other model 
organisms (i.e. yeast) [5], whether the variation is subtle or discrete, one can predict that the whole breath of phenotypic variation is mainly adaptive but this assumption is contingent to the specifics of the measured phenotypes. In other words, not all quantified phenotypes might be important for natural selection, and not all phenotypes under natural selection have been quantified. Thus, when studying subtle variation in naturally occurring variants, robust and unbiased phenotyping methods are ideal.

The raise of geometric morphometric methods has aided the less biased characterization of organs and organisms based on predetermined landmarks, from which the main trends of variation are extracted. Thanks to them, complex phenotypes have been quantified and even genetic bases underlying them have been identified for other organs [6], as well as flowers [7, 8]. Here we use geometric morphometric approaches to quantify floral attributes in the highly complex floral organ of cacti.

In cacti, flowers are described as specialized buds embedded in the tissue of a stem. That is, the ovary is surrounded by material derived from stem or receptacle tissue, forming a structure called pericarpel. The other structure that makes up the flower is the perianth, composed of sepals and petals that develop in a spiral arranged with a gradual transition from green bracts to pigmented structures [9]. The set of both whorls that cannot be distinguished within the first and second whorls are called tepals [10]. Typically, the genus Mammillaria Haw. has a particular type of perianth: flowers are infundibuliform and have a short perianth and a bare pericarpel [11]. In particular, the Mammillaria haageana Pfeiff. flower has a long receptacle tube, the outer tepals are linear-lanceolate with pink to purple pigmentation, and the inner tepals are pink to purple with a darker pink middle stripe [12].

In a previous study, we tested the monophyly of the Series Supertexta in Mammillaria, a group that estimate to have diverged from its sister Series (Polyacanthae), approximately $2.1 \mathrm{Ma}$ ago [13]. Within the Series Supertextae, one of the accepted classifications [14] recognizes nine species, which include: $M$. albilanata Backeb., $M$. crucigera Mart., M. columbiana Salm-Dyck, M. dixanthocentron Backeb., M. flavicentra Backeb., M. haageana, M. halbingeri Boed., M. huitzilopochtli D.R.Hunt, and M. supertexta Mart. Ex Pfeiff.. Within M. haageana, six subspecies have been recognized [15], which include the subspecies: $M$. haageana subsp. haageana, M. haageana subsp. acultzingensis (Linzen et al.) D.R.Hunt, $M$. haageana subsp. conspicua (J.A.Purpus) D.R.Hunt, $M$. haageana subsp. elegans D.R.Hunt, $M$. haageana subsp. meissneri (C.Ehrenb.) U.Guzmán, M. haageana subsp. san-angelensis (Sánchez-Mej.) D.R.Hunt, and M. haageana subsp. vaupelii (Tiegel) U.Guzmán. Among these species, we found that M. haageana units have a convoluted evolutionary history, that might involve $M$. albilanata evolutionary units [13]. This is the reason why we decided to identify patterns of floral variation in $M$. haageana and include M. albilanata as a group for comparisons.

Thus, in this study, geometric morphometrics is used as a method to quantify complex flower phenotypes, and we test whether there is a link between subtle phenotype evolution and the environment within a cacti species (Fig. 1). Secondly, we evaluated taxonomic relationships within the species Mammillaria haageana. We also hypothesize that the morphogeometric variation patterns of the perianth of $M$. haageana support the grouping of infraspecific taxa of the current classification [15]. Therefore, this study aims to characterize, through morphogeometric analysis, the natural variation of the perianth of $M$. haageana. With this, we aimed at identifying what environmental factors might be driving trait evolution in the Mammillaria haageana perianth, as well as the understanding of patterns of morphogeometric variation that might allow the clarification in the classification of infraspecific taxa within the species. Finally, we performed anatomical studies of perianth sections in $M$. haageana subsp. san-angelensis to propose some underlying structural features of the tepal that can provide information about the tepal evolution.

\section{Results}

Four shape principal components describe tepal variation in M. hageana and its sister species

We characterized shape and color-pattern variation in a collection of $20 \mathrm{M}$. haageana accessions that belonged to the six subspecies as previously proposed [15], plus eight accessions from the sister species $M$. albilanata, giving a total of 717 tepals, from 272 flowers, from 28 accessions. We have recently used some of these accessions to characterize the natural variation in root architecture development [16]. To perform the tepal shape analysis, we flattened the perianth and fitted a 13-landmark template on each studied tepal (Fig. 2). First, to extract the tepal shape variation, we performed a Principal Component Analysis (PCA) with Procrustes for rotation, translation, but not size, because size is one of the features that display variation among the $M$. haageana accessions.

We found that $99 \%$ of the variation was covered by eight Principal Components (PCs), but the 7th and 8th capture less than $0.1 \%$ of the variation in each, and their variation was so subtle that could not be described. The first 6 PCs captured $98.59 \%$ of the variation in tepal shape (Fig. 3). The first shape Principal Component $\left(\mathrm{PC1}_{\mathrm{S}}\right)$ a 

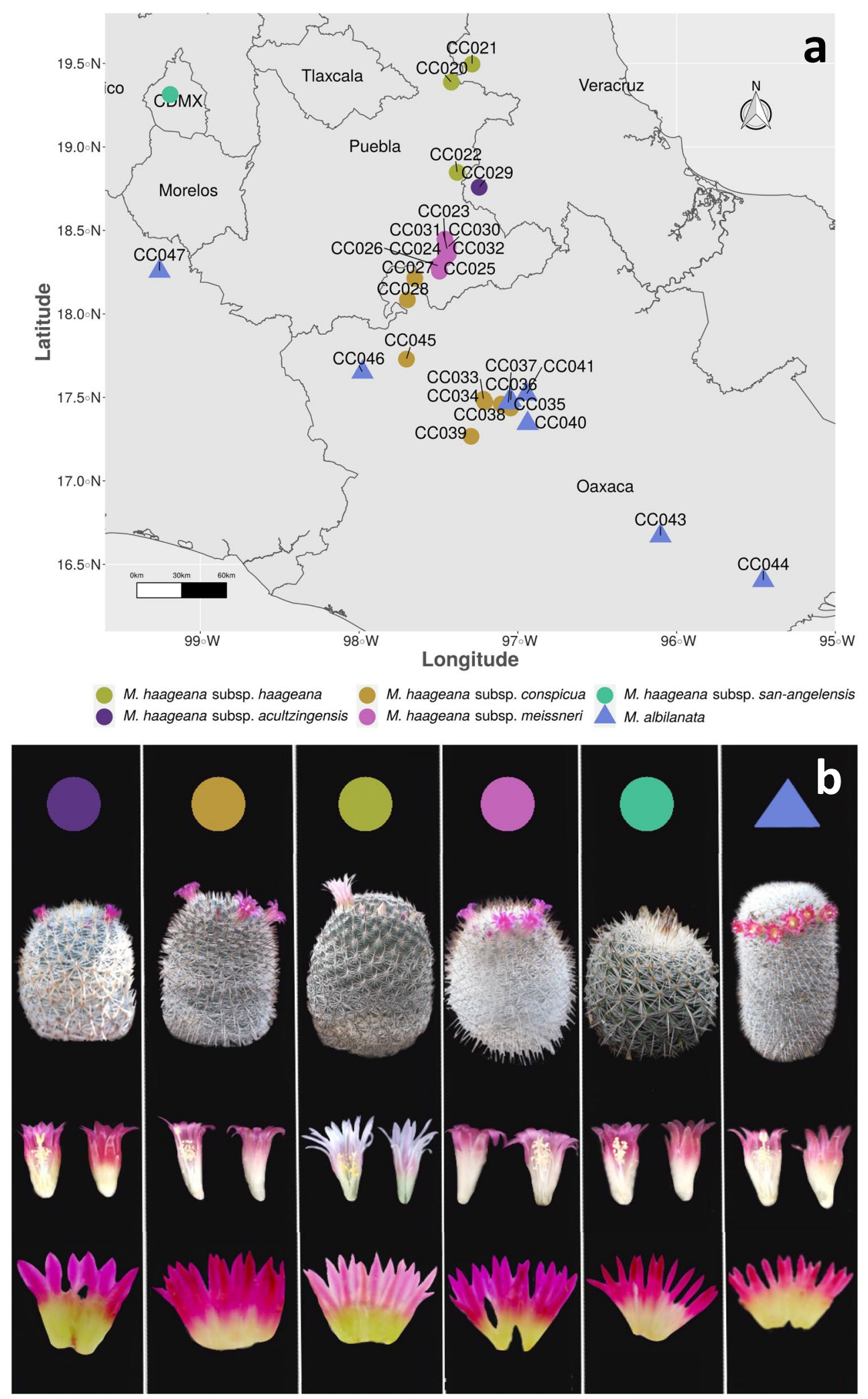

Fig. 1 Mammillaria haageana (and its sister species M. albilanata) distribution and phenotypes, color-coded according to the previously assigned subspecies. a Distribution of collected plant materials. b Plant and flower phenotype variation 
a

b
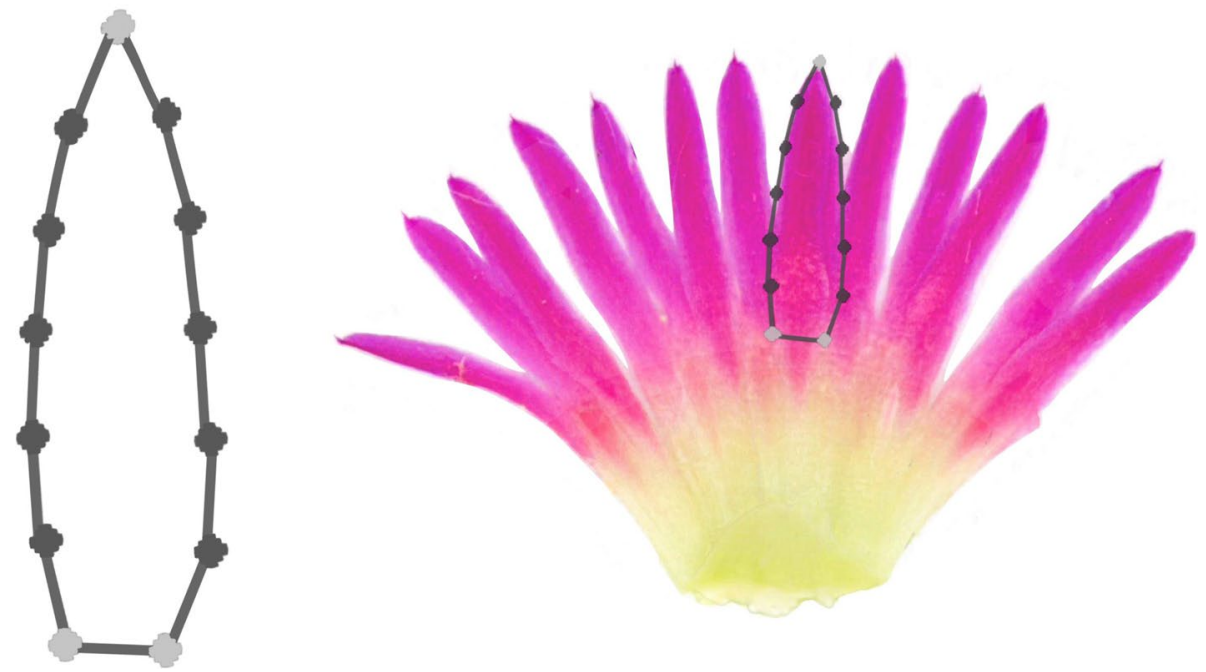

Fig. 2 Template used for the point model in the morphometric analyses. a 13-point model template, including primary landmarks (grey dots), and semi-landmarks landmarks (black dots). b Point-model template overlaid on a tepal from a flattened flower

large proportion of the variation (86.19\%) confirming that $M$. haageana displays wide phenotypic variation in tepal size. Accordingly, $\mathrm{PC}_{\mathrm{S}}$ seems to capture the tepal lamina length. $\mathrm{PC}_{\mathrm{S}}$ is an orthogonal axis to $\mathrm{PC}_{\mathrm{S}}$, and therefore should capture the shape, regardless of the size; thus $\mathrm{PC} 2_{\mathrm{S}}$ captured $5.76 \%$ of the variation and seems to quantify the tepal lamina width. $\mathrm{PC} 3_{\mathrm{S}}$ captured $2.22 \%$ of the variation, and seems to capture whether the tepal is tilted towards the left or the right; however we believe this to be an artefact of the tepal flattening process, and therefore it was not taken into account. $\mathrm{PC} 5_{\mathrm{S}}$ captured $2.16 \%$ of the variation, which seems to capture aspects

\section{$-2 S D$ \\ mean \\ +2 SD \\ variation \\ description \\ $\mathrm{PC} 1_{\mathrm{S}}$
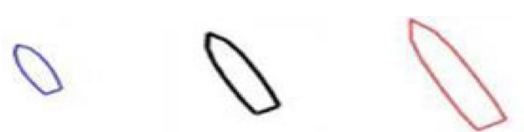 \\ $86.19 \%$ \\ Lamina length \\ $\mathrm{PC}_{\mathrm{S}}$
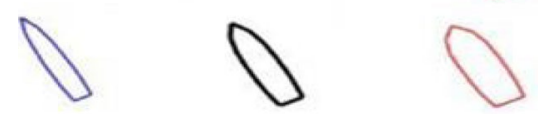 \\ $5.76 \%$ \\ Lamina width \\ $\mathrm{PC}_{\mathrm{S}}$
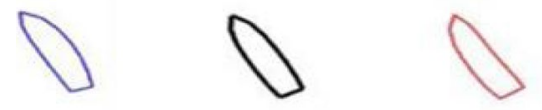 \\ $2.22 \%$ \\ $\mathrm{PC4}_{\mathrm{S}}$
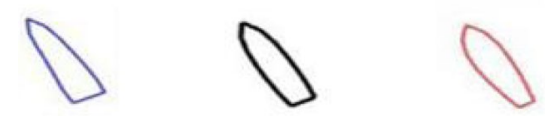 \\ $2.16 \%$ \\ Lamina shape \\ $\mathrm{PC5}_{\mathrm{S}}$
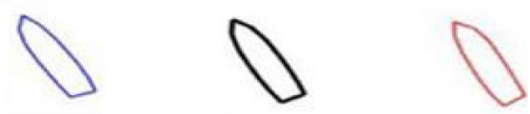 \\ $1.65 \%$ \\ $\mathrm{PC6}_{\mathrm{S}}$
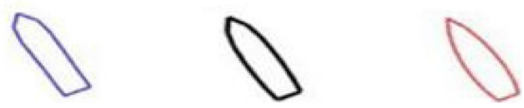 \\ $0.61 \%$ \\ Lamina middle section}

Fig. 3 Tepal shape and size is described by at least six Principal Components $\left(P C_{s}\right)$. The deviations from the mean shape (black outline) are represented in blue ( -2 standard deviations) or in red ( +2 standard deviations). The percentage of explained variance is shown, together with our description of the corresponding $\mathrm{PC}_{\mathrm{S}}$ trend 


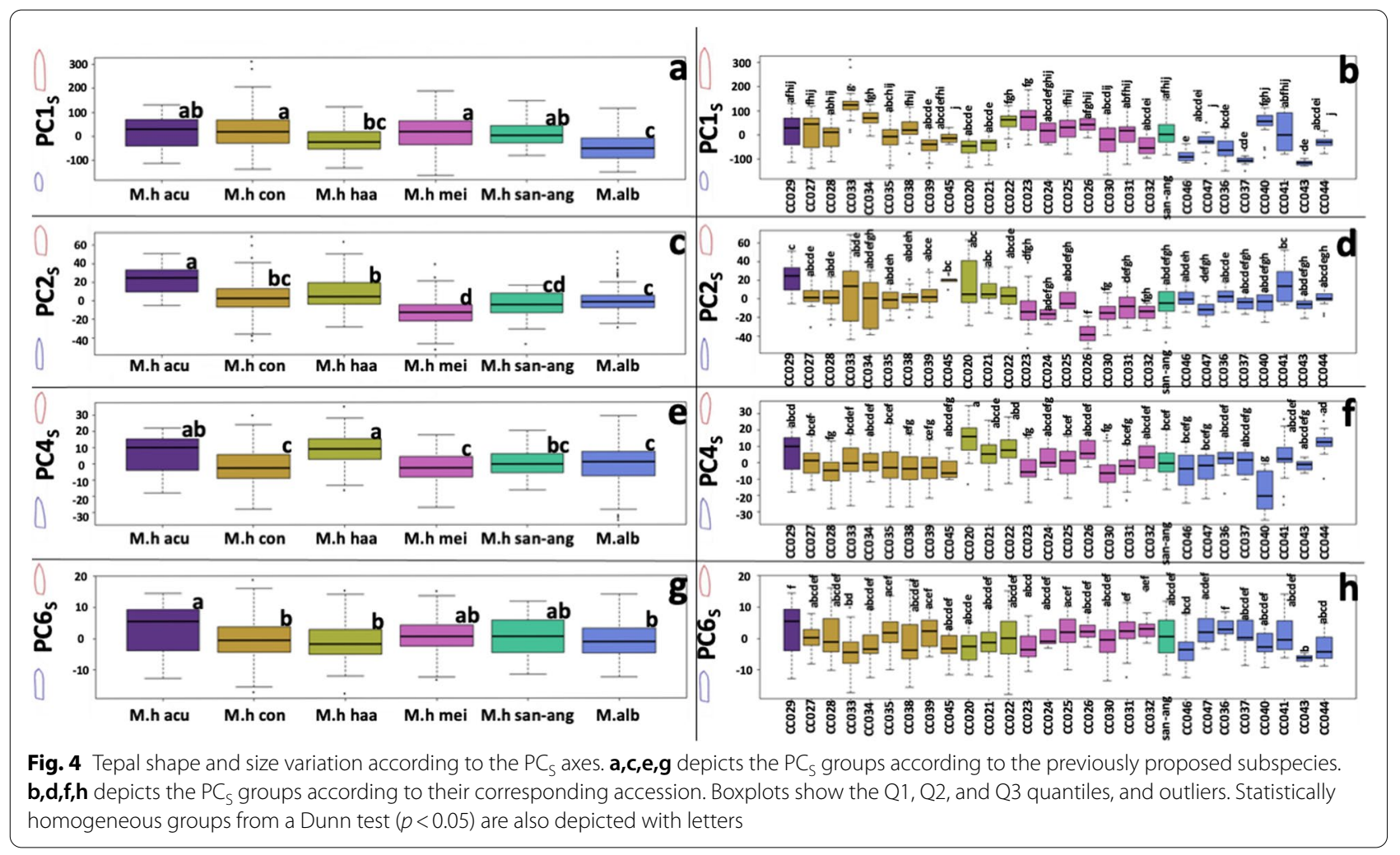

of the tepal lamina shape, such as the width of the proximal end, or the sharpness of the distal end. $\mathrm{PC} 5_{\mathrm{S}}$ captures $1.65 \%$ of the variation but similar to $\mathrm{PC} 3_{\mathrm{S}}$, we believe this to be an artefact of the teal flattening process, and thus it was not further considered. $\mathrm{PC}_{\mathrm{S}}$ captures $0.61 \%$ of the variation and seems to describe the width of the middle section of the lamina. These four shape Principal Components $\left(\mathrm{PC}_{\mathrm{S}}, \mathrm{PC} 2_{\mathrm{S}}, \mathrm{PC}_{\mathrm{S}}\right.$ and $\left.\mathrm{PC}_{\mathrm{S}}\right)$ were then considered to evaluate shape variation in $M$. haageana accessions, plus its sister species $M$. albilanata.

We then plotted the biologically meaningful shape PCs according to their subspecies or their accession (Fig. 4). We noted that according to $\mathrm{PC}_{\mathrm{S}}, M$. albilanata has the smallest tepals, while $M$. haageana subsp. conspicua and $M$. haageana subsp. meissneri had the largest tepals (Fig. 4a). Concerning the lamina width regardless of size $\left(\mathrm{PC} 2_{\mathrm{S}}\right), M$. haageana subsp. acultzingensis had the widest tepals, while $M$. haageana subsp. meissneri had the narrowest tepals (Fig. 4c). On lamina shape $\left(\mathrm{PC}_{\mathrm{S}}\right) \mathrm{M}$. haageana subsp. haggeana had the widest distal end of the tepal, but there were no differences between $M$. albilanata as compared to three other $M$. haageana subspecies (Fig. 4e). On the lamina middle section $\left(\mathrm{PC6}_{\mathrm{S}}\right)$, the subspecies had broad variation and little distinction was observed between them (Fig. 4g).
Despite the variations observed between subspecies, differences between accessions belonging to the same subspecies were far more striking. For instance, on $\mathrm{PC}_{\mathrm{S}}$ we observed ample variation within the $M$. haageana subsp. conspicua accessions, or M. haageana subsp. haageana accessions; but a similar pattern was observed within the M. albilanata accessions (Fig. 4b). This pattern was also observed in the other shape traits $\mathrm{PC}_{S}, \mathrm{PC}_{S}$, and $\mathrm{PC}_{S}$, which was less obvious in the later. In other words, each accession has a distinctive set of shape traits, which seemingly do not agree with their assigned subspecies.

\section{Four color principal components describe tepal variation in M. haageana and its sister species}

Using the geometric morphometric landmark datapoints, we warped all the tepal images into the mean shape, using 10,000 pixels contained in the polygon (Fig. 2) in the RGB channels (30,000 pixels). With this new dataset, we performed a PCA to extract the main trends of variation in tepal color. $95 \%$ of the variation was captured by 47 color PCs. We only present the first 6 PCs, as they seem to capture trends of variation easily be visualized (Fig. 5). Other PCs have very subtle trends that could not be described (data not shown). The first color Principal Component $\left(\mathrm{PC1}_{\mathrm{C}}\right)$ seems to capture the 


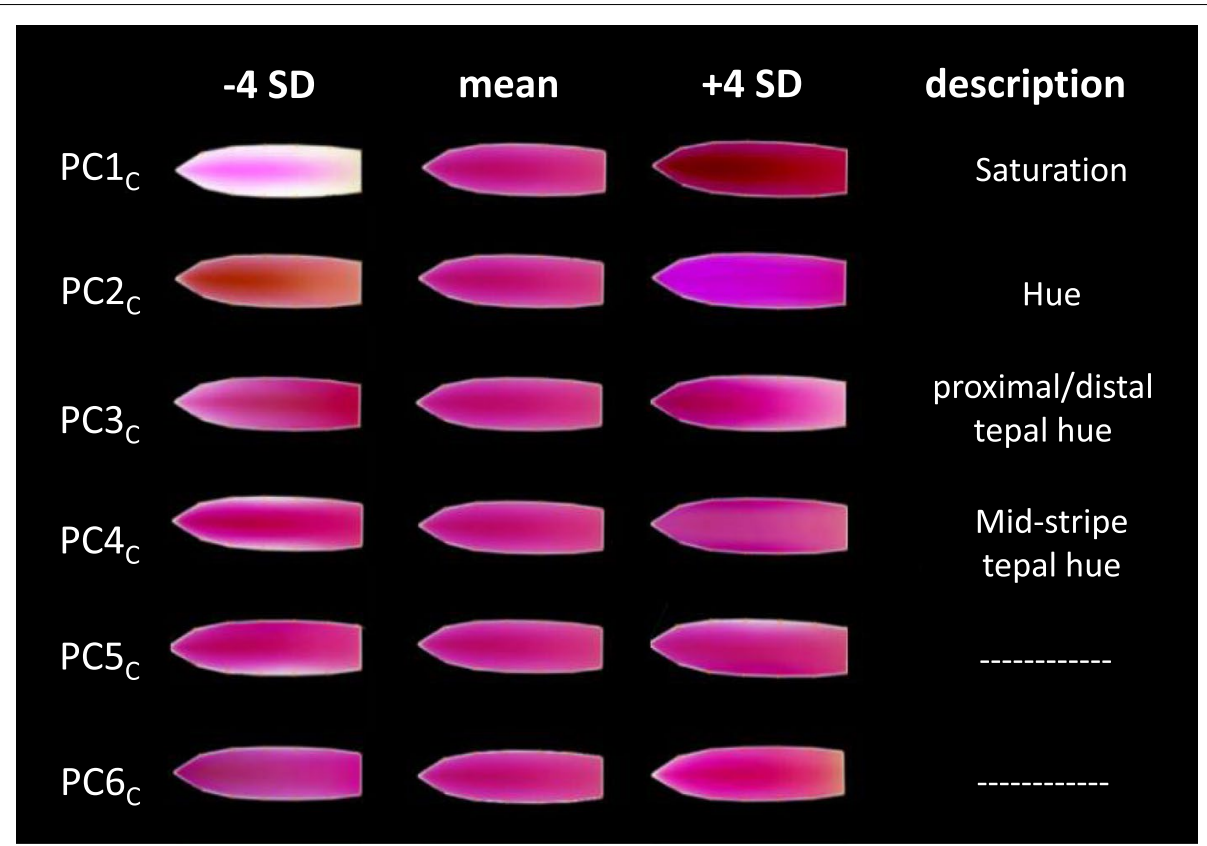

Fig. 5 Tepal color is described by at least six Principal Components $\left(P C_{C}\right)$. The deviations from the mean shape are represented to the left $(-4$ standard deviations) or to the right ( +4 standard deviations). The description of the $\mathrm{PC}_{C}$ trend is shown

color saturation; the $\mathrm{PC} 2{ }_{\mathrm{C}}$ captures the hue of the tepal; $\mathrm{PC}_{\mathrm{C}}$ captures the proximal-distal hue of the tepal, and $\mathrm{PC}_{\mathrm{C}}$ captures the mid-stripe hue. $\mathrm{PC}_{\mathrm{C}}$ seems to capture left-right hue, which we believe to be an artefact because the right or left-handedness of the pigmentation is not observed in $M$. haageana natural accessions. $\mathrm{PC}_{\mathrm{C}}$ was also not described and further considered, as the variation it captures is very subtle. Thus, we propose four color geometric morphometric traits $\left(\mathrm{PC}_{\mathrm{C}}, \mathrm{PC} 2_{\mathrm{C}}\right.$, $\mathrm{PC}_{\mathrm{C}}$ and $\mathrm{PC}_{\mathrm{C}}$ ) in $M$. haageana (and $M$. albilanata) to compare pigmentation patterns between and within subspecies.

Similarly to what we did on the shape, we plotted the biologically meaningful color $\mathrm{PC}_{\mathrm{C}}$ according to their subspecies (Fig. 6). Regarding saturation $\left(\mathrm{PCl}_{\mathrm{C}}\right)$, we found little variation between most $M$. haageana subspecies, except for $M$. haageana subsp. haageana which has lighter saturation tones; on the other hand, M. haageana subsp. san-angelensis has darker saturation tones (Fig. 6a). Concerning hue $\left(\mathrm{PC}_{\mathrm{C}}\right), M$. haageana subsp. acultzingensis had more reddish tepal color as compared to the rest of the $M$. haageana subspecies, but $M$. albilanata had the rather magenta tepal colors (Fig. 6c). On the proximal-distal tepal hue $\left(\mathrm{PC4}_{\mathrm{C}}\right)$, and similar to the distinctive patterns observed in $\mathrm{PC}_{\mathrm{C}}, M$. haageana subsp. haageana has darker magenta pigmentation towards the apex, whereas $M$. albilanata has a darker magenta color towards the proximal end of the tepal
(Fig. 6e). In other words, M. haageana subsp. haageana and $M$. albilanata share pigmentation patterns, but not with the complement of subspecies recognized in $M$. haageana, based on $\mathrm{PC}_{\mathrm{C}}$ and $\mathrm{PC}_{\mathrm{C}}$. Finally, the midstripe tepal hue $\left(\mathrm{PC6}_{\mathrm{C}}\right)$ is more prominent and noticeable in $M$. haageana subsp. haageana, further supporting the distinction of this subspecies from the rest (Fig. 6g).

While differences in color-pattern variations were remarkable between subspecies, when comparing accessions only $\mathrm{PC}_{\mathrm{C}}$ and $\mathrm{PC}_{\mathrm{C}}$ showed broad differences between accessions, even from the same subspecies. This was the case of $M$. haageana subsp. meissneri on $\mathrm{PC}_{\mathrm{C}}$, in which $\mathrm{CC} 031$ has significantly lower $\mathrm{PC} 1_{\mathrm{C}}$ value (saturation) than CC030. Another example is the A. albilanata accession CC044 in which there is ample variation between individuals of the same accession, that is noticeable by the amplitude of the boxplot (Fig. 6b). Remarkably, $M$. haageana subsp. haageana accessions are similar to one another in $\mathrm{PC}_{\mathrm{C}}$ and $\mathrm{PC} 4_{\mathrm{C}}$.

\section{Phenetic analyzes suggests possible natural groups}

Both shape and pigmentation analyses provided quantitative parameters of novel axes to compare the accessions of $M$. haageana and its sister species $M$. albilanata. As shown in Fig. 4 and Fig. 6, some traits partially recapitulate subspecies classifications, but others do not. To unravel the possibility that these traits could recapitulate the subspecies classification, a series of multivariate 


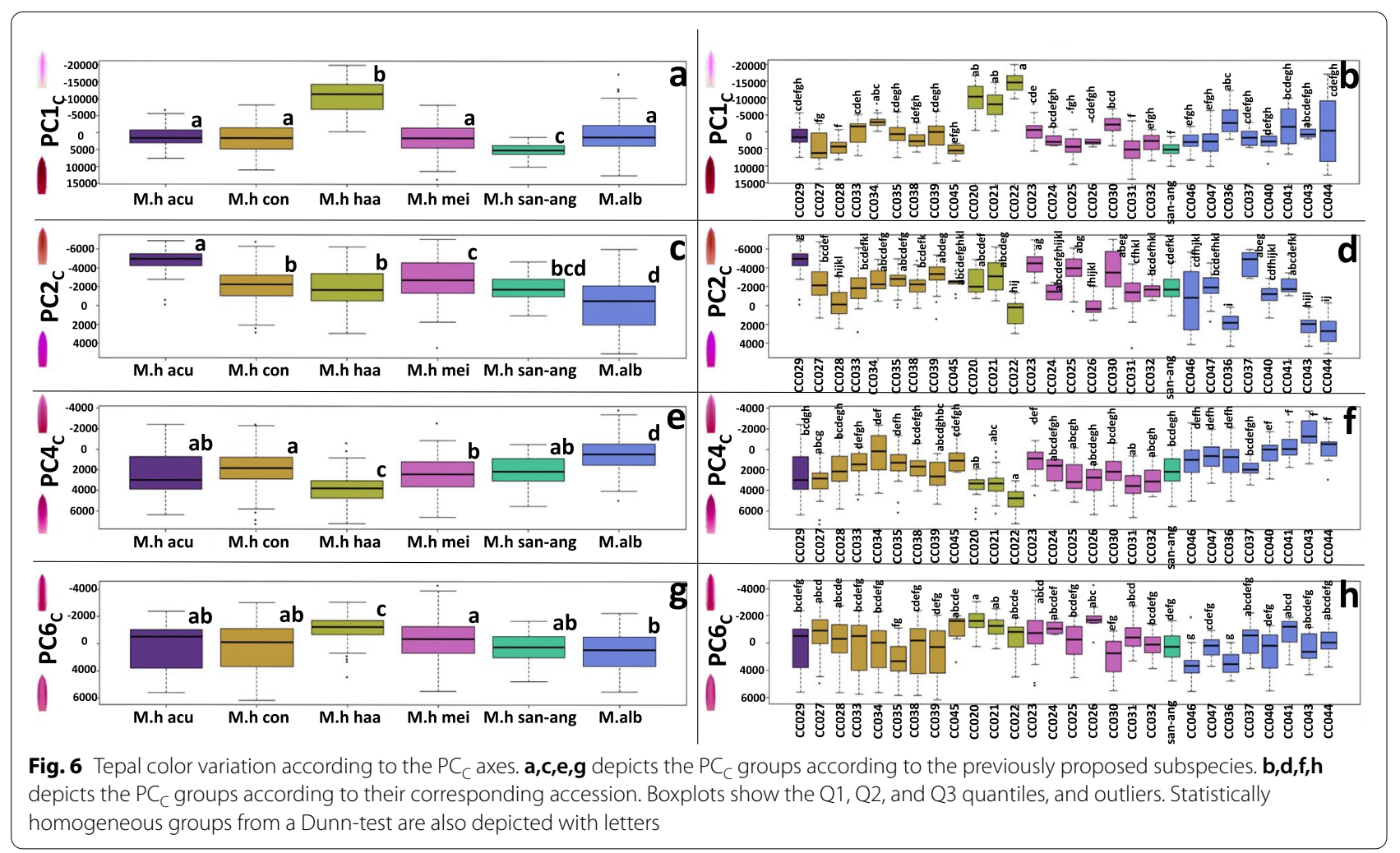

analyses were performed. First, a Linear Discriminant Analysis (LDA) with shape traits was implemented to test whether the four $\mathrm{PC}_{S}$ parameters separated the five subspecies plus the sister species (Fig. 7a). This model gave a precision of $65.45 \%$ in the correct assignment of accessions. In other words, in an LDA, the four shape components in $M$. haageana failed to create a distinction between the five subspecies and the sister species. Subsequently, the four parameters corresponding to pigmentation were tested (PCc). The model gave a $80.67 \%$ accuracy in assigning the accessions to the subspecies. Nevertheless, in this analysis it was possible to see the separation of two groups of accessions corresponding to $M$. haageana subsp. conspicua and M. haageana subsp. san-angelensis (Fig. 7b). Finally, we performed a third LDA combining the eight components corresponding to shape $\left(\mathrm{PC}_{\mathrm{S}}\right)$ and color $\left(\mathrm{PC}_{\mathrm{C}}\right)$. This model has an accuracy of $71.32 \%$ in assigning subspecies. In this case, the two groups of accessions that separated from the rest were the species $M$. albilanata and the subspecies $M$. haageana subsp. haageana (Fig. 7c). In summary the LDA of shape and pigmentation parameters only partially recapitulated some of the previously proposed taxonomic units [15].

We also used another multivariate method based on Euclidean distances to test whether the taxonomic units can be recapitulated. This gave groupings between the accessions based on shape and color. It was observed that the accessions CC020, CC021 and CC022, corresponding to the subspecies $M$. haageana subsp. haageana, are grouped in a single branch as compared to the rest of the accessions (Fig. 7d). This result might indicate that the combination of shape and color parameters in M. haageana subsp. haageana could indeed define this group as a subspecies within $M$. haageana.

Pigmentation patterns are known to have impacts on color reflectance, and therefore color perception by pollinators, as demonstrated in Antirrhinum [17]. In order to test whether the environment might play a role in determining tepal pigmentation patterns in M. haageana, we performed an association analysis of solar radiation with our shape and color PCs (Fig. 8a). Interestingly, we found several correlations between solar radiation, with tepal shape and color. For simplicity, we show the plots of the six highest correlations between the environment and tepal attributes (Fig. 8b-g). Regarding tepal shape, we found that global horizontal radiation (GHI) and air temperature (TEMP) were negatively correlated with $\mathrm{PC}_{\mathrm{S}}$ (lamina width) (Fig. 8b-c), implying that narrower tepal accession originates from cooler locations with lower global horizontal irradiation, while wider tepal accessions originated from 


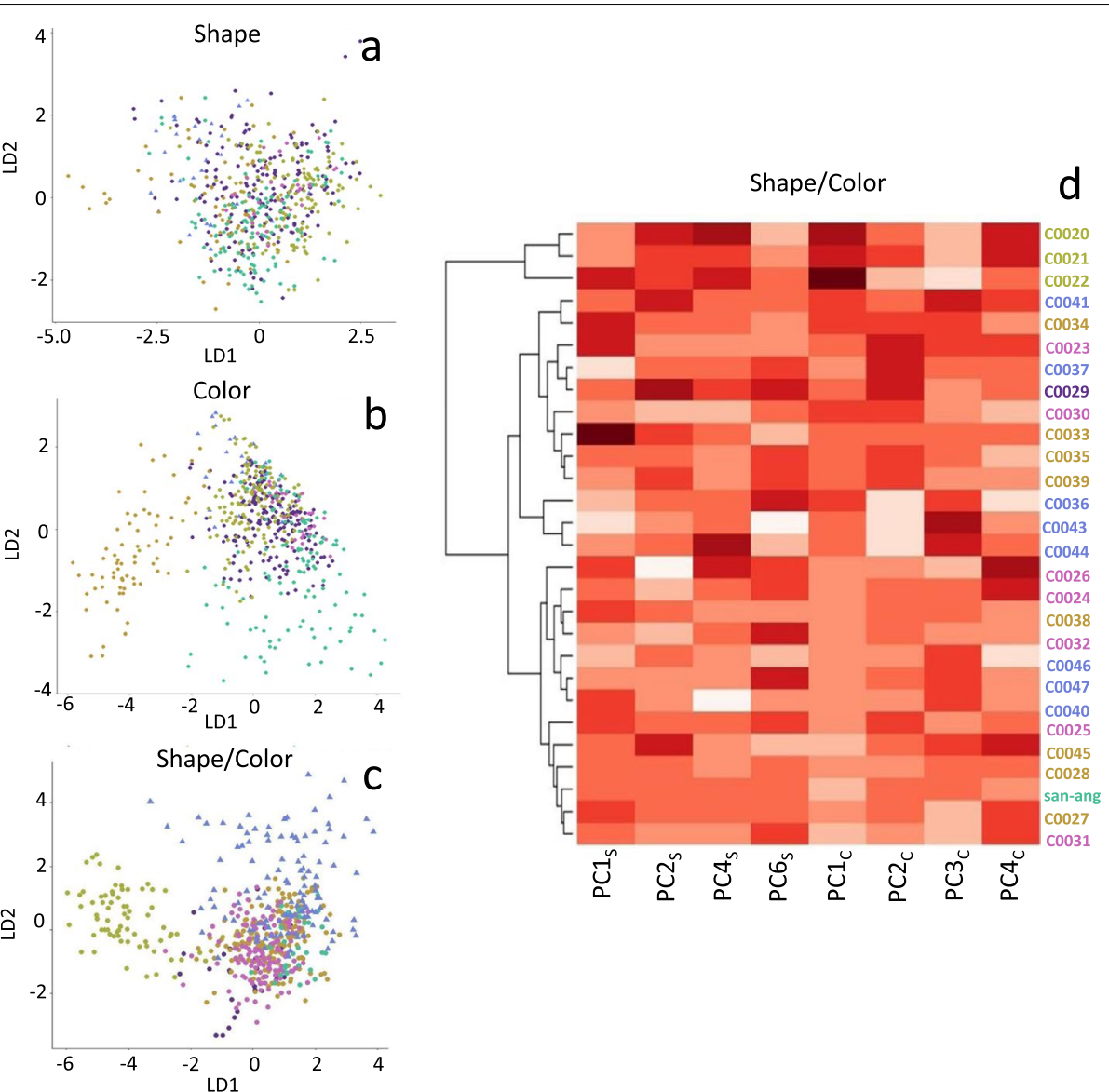

Fig. 7 Multivariate analysis of flower phenotypes. a LDA of flower phenotypes using only $\mathrm{PC}_{\varsigma}$ (shape) values. $\mathbf{b}$ LDA of flower phenotypes using only $\mathrm{PC}_{C}$ (color) values. $\mathbf{c} L D A$ of flower phenotypes using both $\mathrm{PC}_{S}$ (shape) and $\mathrm{PC}_{C}$ (color) values. $\mathbf{d}$ Euclidean distance clustering and heat map using both $\mathrm{PC}_{\mathrm{S}}$ (shape) and $\mathrm{PC}_{\mathrm{C}}$ (color) values

warmer and higher global horizontal irradiation locations. We also found a positive correlation between the organ shape parameter $\mathrm{PC6}_{\mathrm{S}}$ (lamina middle section) and global horizontal radiation (GHI) (Fig. 8d), which interpretation requires further examination. Regarding tepal color, we found that $\mathrm{PC} 1_{\mathrm{C}}$ (saturation) has a negative correlation with diffuse horizontal radiation (DIF) (Fig. 8e); this means that darker tepals are present in accessions originally from locations with lower DIF, while lighter tepals are present in accessions originally from locations with higher DIF. Another interesting negative correlation was found between $\mathrm{PCl}_{\mathrm{C}}$ (saturation) and air temperature (TEMP) (Fig. 8f), in which paler tepals (low $\mathrm{PC} 1_{\mathrm{C}}$ ) were from accessions originally from lower TEMP locations, as opposed to darker tepals (high $\mathrm{PC}_{\mathrm{C}}$ ) which were from accessions from higher TEMP locations. On the other hand, $\mathrm{PC}_{\mathrm{C}}$ (mid-stripe tepal hue) was positively correlated with direct normal radiation (DNI) (Fig. 8g), in which the more noticeable mid-stripe (low $\mathrm{PC}_{\mathrm{C}}$ ), the lower DNI; meanwhile the less noticeable mid-stripe (high $\mathrm{PC}_{\mathrm{C}}$ ) the higher DNI. Overall, these results allowed us to establish a link between tepal shape and pigmentation patterns, and the environment, which might definitely have adaptive bases.

In order to provide a possible anatomical explanation on the origins of shape and color variation in $M$. haageana tepals, we examined the tepal anatomy of $M$. haageana subsp. san-angelensis (Fig. 9). To do this we performed histological sections of the proximal, middle, and distal sections of the tepals, and characterized the tepals qualitatively and quantitatively. We obtained that epidermis of the abaxial and adaxial sides are fairly similar to each other, and also similar cell size at the distal or proximal end of the tepal. These sections suggest that color variation along the transversal and longitudinal sections of the tepal lamina does not originates within the epidermis cell shape, and possibly the variation between accessions either. Thus, the variation in tepal color that we characterized between accessions must be given by 

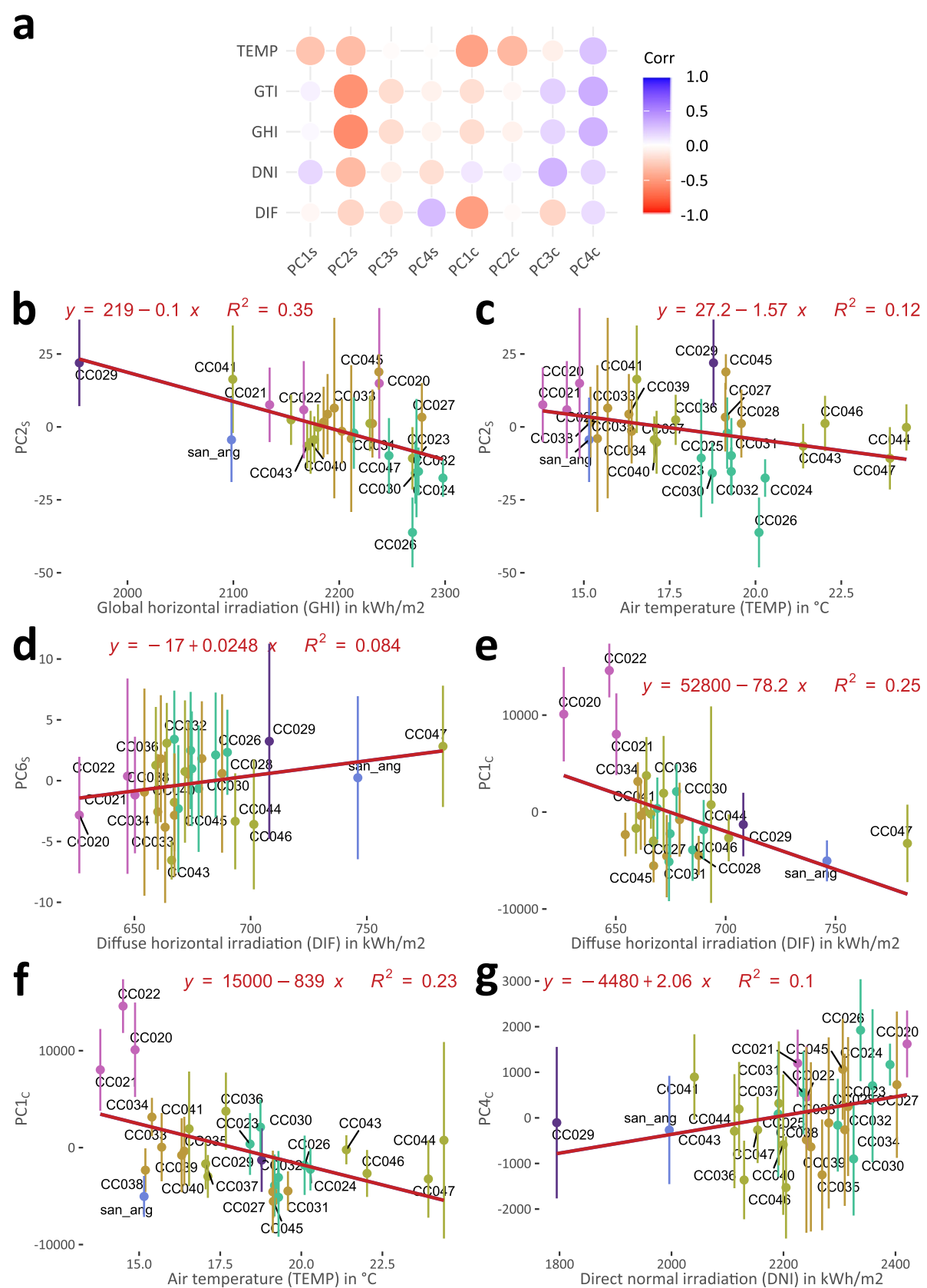

Fig. 8 Tepal shape and color are correlated to environmental variables. a Solar radiation environmental variables and their correlation to shape $\left(P C_{s}\right)$ and color $\left(P C_{C}\right)$. b-d Top correlations of solar radiation variables to tepal shape $\left(P C_{s}\right)$. $\mathbf{e}-\mathbf{g}$ Top correlations of solar radiation variables to tepal color $\left(\mathrm{PC}_{\mathrm{C}}\right)$. GHI, long-term yearly average Global Horizontal Irradiation; DNI, long-term yearly average of Direct Normal Irradiation; DIF, long-term yearly average of Diffuse Horizontal Irradiation; GTI, long-term yearly average of Global Irradiation at Optimum Tilt (kWh/m²); and TEMP, long-term yearly average of air Temperature $\left({ }^{\circ} \mathrm{C}\right)$. Accessions are color-coded according to the previous subspecies classification. Dots represent the mean PC value for each accession, and lines represent the standard deviation from the mean

the variation in betalain (purple color) and betaxanthin (yellow color) pigments, which concentrations remain to be quantified. Last, within the mesophyll we found large mucilage bodies, which sometimes seemed to be large single cells, but in some other cases, these mucilage bodies were surrounded by small cells. These mucilage bodies had a variety of sizes and occupied most of the mesophyll tissue towards the distal part of the tepal and were rather small at the proximal end of the tepal. On the other hand, the tepal was highly vascularized towards 

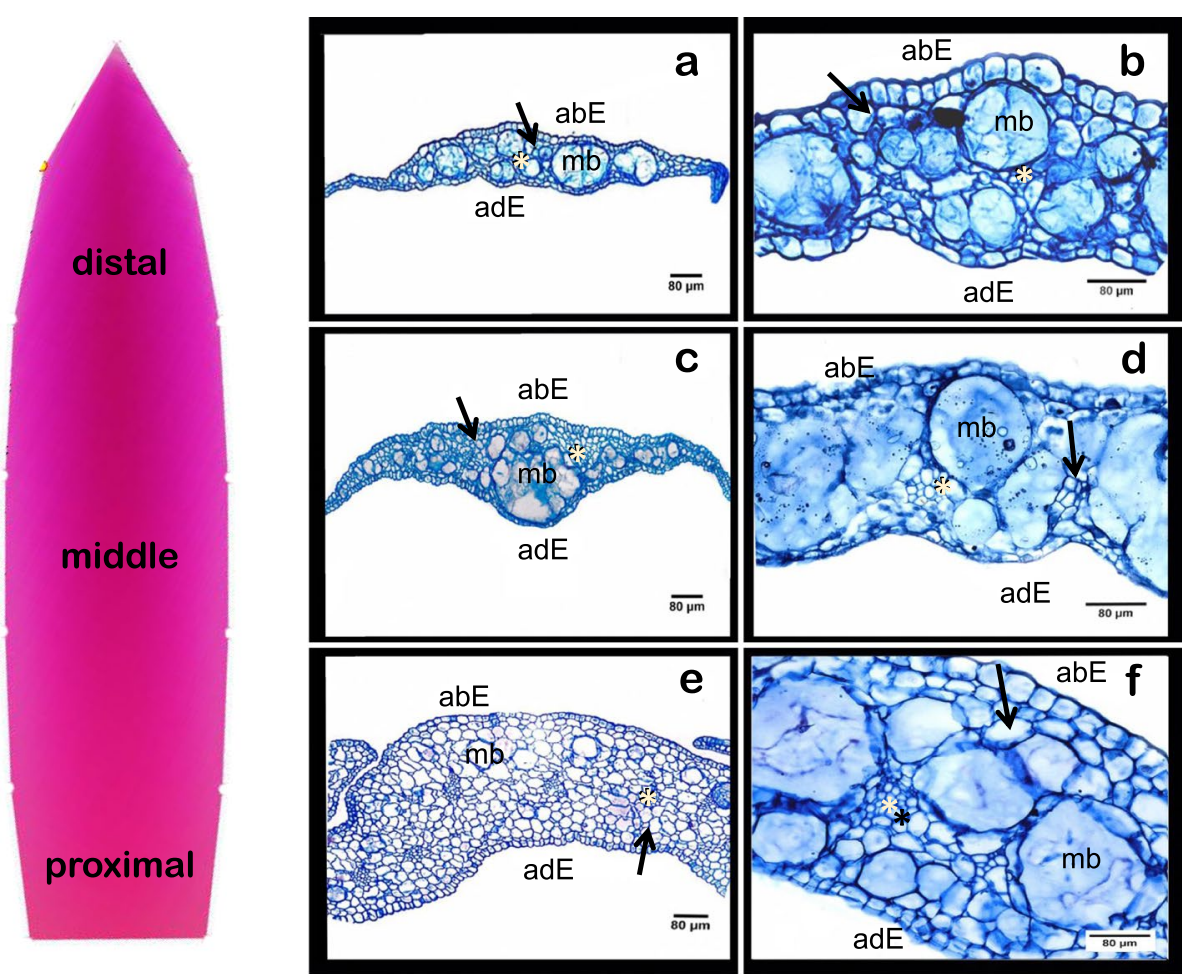

Fig. 9 Cross-section of in Mammillaria haageana subsp. san-angelensis along different longitudinal regions. a-b distal section, c-d middle section, and $\mathbf{e}$-f proximal section. A modeled tepal is shown on the left-hand side for reference. abE abaxial epidermis, adE adaxial epidermis, mb mucilage body, light asterisk indicates vascular bundles, and black arrows represent mesophyll cells

the proximal end, but fewer or smaller vascular bundles were observed towards the distal end. In leaves, vascular bundles are more prominent towards the leaf base, and at the apex they become mere vascular endings with tracheal elements. In the context of cacti tepals, this inverse relationship of vasculature versus mucilage bodies in the mesophyll might be part of the tepal adaptation for the flower to avoid desiccation towards the distal end, but maintain water flow towards the proximal end. Finally, to contextualize what we observed in $M$. haageana subsp. san-angelensis, we found that tepal anatomy is fairly similar to what has been observed in tepals of Epiphyllum phyllanthus [18], another distantly related cacti species, suggesting that tepal anatomy is fairly constant in the Subfamily Cactoideae.

\section{Discussion}

In this work we studied the natural variation of flower shape and color between subspecies and accessions of $M$. haageana and its closely related species $M$. albilanata. Using geometric morphometric methods, we established eight multivariate quantitative parameters to describe variation on several tepal features. When grouping together the tepals from each subspecies, we found little variation between the allometric phenotypes, however, when teasing apart the variation from each accession, we found a wide range of variation within each subspecies. One exception was $M$. haageana which in at least four allometric parameters were distinctive from the rest. The other exception was M. albilanata which in some other parameters were distinctive. Phenetic multivariate analyses using the geometric morphometric parameters showed that the subspecies, except for $M$. haageana subsp. haageana and M. albilanata, show that accessions do not group together according to the subspecies they belong to. In fact, the accessions rather group according to global horizontal irradiation (GHI) and mainly, among other environmental factors. This can be interpreted in two ways: a) the evolution of shape and size in M. haageana is independent from subspecies divergence, or b) the current subspecies classification is not natural. Further studies are required to respond to this issue.

Pollinator occurrence can sometimes explain flower color variation within species, but in some other instances it is rather abiotic factors such as temperature and solar irradiation what underlies color variation, as was the case of Campanula americana (Campanulaceae) [19]. This is because solar irradiation indirectly affects 
the pollinator behavior by modifying floral temperature, or color perception. Nevertheless, it has also been found that floral color variation can also be explained by phenotypic plasticity. This was the case of the selfing species Boechera stricta (Brassicaceae), whose flower colors in natural populations ranges from mostly white, to pink and purple colors; it was found that floral pigmentation was higher when plants were studied in the field, as opposed to plants in greenhouse conditions; yet from the later experiments it was determine that flower color is highly heritable when comparing populations [4]. The authors proposed that increased flower pigmentation is correlated to biotic and abiotic stresses in natural conditions. This poses the possibility that $M$. haageana flower shape and color variation might be a byproduct of solar radiation on pollination behavior, or that this variation might give fitness benefits under the wide range of environments where the accessions originate from.

Resolving the phylogenetic relationships between and within species of the Mammillaria genus has been a challenging puzzle for cacti taxonomists. Here we addressed the problem of floral attribute variation in M. haageana, taking into account several accessions belonging to subspecies according to previous classifications [15]. Yet, in most cases our tepal shape and color analyses did not manage to recover the proposed infraspecific categories. Some possible explanations are that: a) the infraspecific classification is natural, but $M$. haageana flowers have evolved independently from the diagnostic characters that were used to establish the subspecies, or b) an update on the infraspecific categories is required, taking into account not only floral characters, but vegetative and genomic evidences. Nevertheless, our multivariate analyses clearly identify some of the previously proposed taxa, such as $M$. haageana subspecies haageana, suggesting that this group might indeed be natural.

Ample evidence has demonstrated the close relationships between pollinators and the reproductive success of several cacti species [20-23]. In this regard, in other model species such as Antirrhinum (Plantaginaceae), epidermal cell shape could modify the color and perception of pollinators [17]. Although we only studied one accession (M. haageana subsp. san-angelensis) and pigmentation patterns vary along the transversal axis of the tepal, we did not find evidence of epidermis cell shape variation along the transversal or longitudinal sections, possibly suggesting that natural variation in pigmentation patterns might be rather explained by the type of pigments contained within the tepals. Furthermore, given the proportional size of the mucilage bodies within the mesophyll of the tepals, it is possible that within these mucilage bodies, the pigments (in cacti mainly betalains and betaxanthins) are stored, as well as in the epidermal cells, or subepidermal cells as has been previously found in cacti stems [24]. Regarding this, cacti flowers are severely exposed to high irradiation and temperature, and the presence of abundant mucilage bodies in the mesophyll might be an important anatomical adaptation to cope with those challenging environments. Given our observed correlation of solar irradiation and tepal pigment and shape, it remains to be addressed whether mucilage bodies might be involved in the natural variation and connection to solar radiation that we observed in this study.

Overall, the ample distribution and variety of environments that $M$. haageana occupies, opens new avenues of research to understand local adaptations, how traits evolved, and the evolutionary history of these natural variants. However, as in any phenotype characterized in a common environment, away from the natural distribution of the species, it remains to be tested whether the phenotypes in the field are identical to the phenotypes in the wild; yet we have no evidence to think otherwise. This is because floral meristems in succulent plants obtain their resources from their storage parenchyma accumulated over the years, rather than the prevailing soil conditions in a particular reproductive year. This is why we believe that $M$. haageana could be a model system to address relevant questions on the microevolution of succulent plants.

\section{Materials and methods \\ Plant material}

Two species of the genus Mammillaria series Supertextae were used, $M$. haageana and its sister species $M$. albilanata. The material was obtained from the Jardín Botanico at Instituto de Biología, UNAM Cactaceae Collection, where only five subspecies of Mammillaria haageana out of the seven were previously collected from the field, and deposited as living material for research purposes $[15,16]$. Therefore, we used $M$. haageana subsp. haageana, $M$. haageana subsp. conspicua, M. haageana subsp. meissneri, M. haageana subsp. acultzingensis and $M$. haageana subsp. san-angelensis, as identified by CCS and SA, the cacti taxonomists in our research team. In the case of Mammillaria albilanata, only two subspecies were included, $M$. albilanata subsp. albilanata and $M$. albilanata subsp. oaxacana were used as the sister species for comparison. The specimens were assigned a code according to the locality in which they were collected. For future reference, the set of specimens belonging to a locality were called accessions. This to distinguish them, as we still do not know whether they can be considered as populations. From each plant, four individuals were selected per accession. In some accessions there were only three available individuals. From each individual, we aimed to 
collect three flowers in anthesis from each selected plant, but in some cases, we could only collect one or two flowers. In other words, we aimed at collecting 12 flower samples per accession, but in some cases we had fewer (Additional file 1). This gave a total of 28 accessions and 239 flattened flowers (Additional dataset 1).

\section{Morphometric analysis of shape}

To obtain images of flattened tepals, first we removed one of the two rings of tepals (the outer tepals because often they have bracteole features). Then the remaining perianth was flattened over paper sheets using double-sided tape (Double-sided adhesive tape, () Red Top $(18 \mathrm{~mm} \times 20 \mathrm{~m}))$. Subsequently, all the sheets of paper with the flattened perianth were scanned at a resolution of 1200 dots per inch (DPI) using an Epson Perfection V550Photo scanner. In this way, two-dimensional images of the dorsal view of the perianth, and particularly the inner tepals were obtained. From each flattener flower image, we selected three tepals for geometric morphometric analyses, which involved 699 tepals in total (Fig. 2a).

To generate allometry models we placed reference points on the tepal images. In Mammillaria, some part of the tepal might be fused or emerge deep down from the pericarpel. However, to simplify our analysis, we only took into account the portion of the tepal that is not fused, the tepal lobe. Thus, a 13-point model template was designed to capture the tepal shape of $M$. haageana, and its sister species M. albilanata. The model template was made of two types of points: primary and secondary landmarks. The primary landmarks, depicted in Fig. 2a in light grey, were fixed to distinguishable features of the tepals, such as the left or right corner at the base of the tepal lobe, or the tip of the tepal. The base of the tepal lobe was designated as the lowest point where two tepals are not fused, and tepals are pigmented. The secondary points, depicted in Fig. 2a in dark grey, were placed along the outline of the tepal, in such a way that they were evenly spaced between the primary landmarks. The point model was designed with the shape model AAMToolbox program $[25,26]$ implemented in the Matlab environment (Version 7.12.0.635).

To obtain size and shape variables from Cartesian coordinates, Procrustes Analysis (PA) was implemented in all images. The PA is a tool that allows comparing two homologous point configurations from two variants of the same entity. The first transformation operation was the translation, based on the displacement of all the points at a fixed distance in a certain direction. The second transformation operation was the rotation operation, which consists of moving all the points using a fixed angle around an axis. The third often used transformation, the scaling method, or uniform change of scale, was not applied within the study. This was done to take into account the size variation as an important factor to quantify, in addition to the shape. The analysis was carried out with capture of $99 \%$ of the variation in the values along the length, width, and curvature of the tepals in the different accessions. Once the shapes were aligned with the PA, a Principal Component Analysis was performed to determine the possible variations in the shape of the tepals.

\section{Morphometric analysis of color}

The same specifications of the PA were applied for the Analysis of Principal Components of Coloring $\left(\mathrm{PC}_{\mathrm{C}}\right)$. In $\mathrm{PC}_{\mathrm{C}}$ analysis, all images were warped to the average tepal shape using the AAMToolbox program $[25,26]$. In this way, instead of comparing the cardinal points, the pixels of each of the appropriate shapes were compared. In total, 30,000 px per image were used based on the RGB (Red, Green, Blue) color model. That is, each image presented 10,000 px and, when multiplied by the three additive primary color components, they gave a total of 30,000 data for the $\mathrm{PC}_{\mathrm{C}}$.

\section{Statistical analysis}

Principal Component matrices were obtained with the variances of all the main components, both in shape and in color. Of the total components obtained, those that presented modifications in their shape and pigmentation due to the handling of the material were not considered for further analyses. In the end, four components for shape $\left(\mathrm{PC}_{\mathrm{S}}\right)$ and four components for coloring $\left(\mathrm{PC}_{\mathrm{C}}\right)$ were obtained.

To contrast, the normality of the data, a Shapiro Wilk test was applied. The homogeneity of the variances between the accessions was evaluated with a Levene-test. Because the data did not comply with the assumptions of normality and homoscedasticity, we used non-parametric statistics. Therefore, the significance between the differences in the shape and coloration of the accessions was determined with a Kruskal Wallis test. Finally, to determine the pairs of significantly different groups, a post hoc test (Dunn's test) was applied on $\mathrm{PC}_{\mathrm{S}}$ and $\mathrm{PC}_{\mathrm{C}}$. All these downstream data analyses of $\mathrm{PC}_{\mathrm{S}}$ and $\mathrm{PC}_{\mathrm{C}}$ were done using in R (version 2.6.2) [27].

Linear Discrimination Analysis was performed on PCA scores to test the possibility of discriminating the subspecies using morphological shapes and color patterns. Besides the LDA analysis, we also performed a phenetic clustering analysis by using the average PCA values of the accession. We performed all analyses with the complete dataset, including all accession belonging to the 
subspecies of $M$. haageana and the data set related to the sister species M. albilanata.

\section{Correlation to solar radiation variables}

We obtained five environmental variables linked to solar radiation, from the Global Solar Atlas database [28]: GHI, long-term yearly average Global Horizontal Irradiation $\left(\mathrm{kWh} / \mathrm{m}^{2}\right)$; DNI, long-term yearly average of Direct Normal Irradiation $\left(\mathrm{kWh} / \mathrm{m}^{2}\right)$; DIF, long-term yearly average of Diffuse Horizontal Irradiation $(\mathrm{kWh} /$ $\mathrm{m}^{2}$ ); GTI, long-term yearly average of Global Irradiation at Optimum Tilt $\left(\mathrm{kWh} / \mathrm{m}^{2}\right)$; and TEMP, long-term yearly average of air Temperature $\left({ }^{\circ} \mathrm{C}\right)$. All of them covered a period of 1999-2018, except for TEMP, which covered a period of 1994-2008. All variables were obtained in tif format and adjusted to a 30 arch seconds (approximately $1 \mathrm{~km}$ resolution at the Equator). The values were extracted from the occurrence locations, using the packages raster ver. 3.4.5 and sp. ver 1.1.4. We used the Pearson coefficient to analyze the correlation between the morphological and solar environmental variables.

\section{Abbreviations}

abE: Abaxial epidermis; adE: Adaxial epidermis; DIF: Long-term yearly average of Diffuse Horizontal Irradiation; DNI: Long-term yearly average of Direct Normal Irradiation; GHI: Long-term yearly average Global Horizontal Irradiation; GTI: Long-term yearly average of Global Irradiation at Optimum Tilt; mc: Mucilage body; LDA: Linear Discriminant Analysis; PCA : Principal Component Analysis; PC : Color Principal Components; CC$_{5}$ : Shape Principal Components; RGB: Red, Green, and Blue pixel channels; SD : Standard deviations; subsp. : Subspecies; TEMP: Long-term yearly average of air Temperature.

\section{Supplementary Information}

The online version contains supplementary material available at https://doi. org/10.1186/s12870-021-03386-8.

Additional file 1 Full list of analyzed images, and their corresponding calculated Principal Components for shape $\left(P C_{S}\right)$ and color $\left(P C_{C}\right)$. Additional dataset 1. Full collection of flattened flowers doi: https://doi.org/10.6084/ m9.figshare.14103437.

\section{Acknowledgments}

CRC is a doctoral student from Programa Posgrado de Ciencias Biológicas, Universidad Nacional Autónoma de México (UNAM), and received the fellowship 631251 from Consejo Nacional de Ciencia y Tecnología (CONACyT-México).

\section{Authors' contributions}

UR, ESFP, CRC, ISS, JRS and SA conceptualized the project; UR, CRC, ISS, JRS, and SA collected and maintained the plant material; ESFP collected the flowers and gathered geometric morphometric data; ESFP and ESZ obtained the anatomical sections; UR, ESFP and CRC analyzed the data; UR wrote the manuscript; UR edited and submitted the revised manuscript. The authors read and approved the final manuscript.

\section{Funding}

This research was funded by PAPIIT-DGAPA-UNAM grant number IN211319 to UR. The funder had no role in study design, data collection and analysis, decision to publish, or preparation of the manuscript.

\section{Availability of data and materials}

All living plant materials are now part of the cacti collection at Jardín Botánico, Instituto de Biología, UNAM. All images used to perform the geometric morphometric analyses were submitted to a public repository doi: https://doi.org/ 10.6084/m9.figshare.14103437.

\section{Declarations}

Ethics approval and consent to participate

Not applicable.

\section{Consent for publication}

Not applicable.

\section{Competing interests}

We declare that we have no significant competing financial, professional, or personal interests that might have influenced the performance or presentation of the work described in this manuscript.

\section{Author details}

1Jardín Botánico, Instituto de Biología, Universidad Nacional Autónoma de México, 04510 Mexico City, Mexico. ${ }^{2}$ Posgrado en Ciencias Biológicas, Universidad Nacional Autónoma de Mexico, Mexico City, Mexico.

Received: 29 September 2021 Accepted: 1 December 2021

Published online: 25 January 2022

\section{References}

1. Clegg MT, Durbin ML. Flower color variation: a model for the experimental study of evolution. Proc Natl Acad Sci. 2000;97:7016 LP-7023. https:// doi.org/10.1073/pnas.97.13.7016.

2. He Q, Shen $Y$, Wang M, Huang M, Yang R, Zhu S, et al. Natural variation in petal color in Lycoris longituba revealed by anthocyanin components. PLoS One. 2011;6:e22098. https://doi.org/10.1371/journal.pone.0022098.

3. Bradley D, Xu P, Mohorianu I-I, Whibley A, Field D, Tavares H, et al. Evolution of flower color pattern through selection on regulatory small RNAs. Science. 2017;358:925-8.

4. Vaidya P, McDurmon A, Mattoon E, Keefe M, Carley L, Lee C-R, et al. Ecological causes and consequences of flower color polymorphism in a self-pollinating plant (Boechera stricta). New Phytol. 2018;218:380-92. https://doi.org/10.1111/nph.14998.

5. Ho W-C, Ohya Y, Zhang J. Testing the neutral hypothesis of phenotypic evolution. Proc Natl Acad Sci. 2017;114:12219-24. https://doi.org/10. 1073/pnas.1710351114.

6. Rosas U, Cibrian-Jaramillo A, Ristova D, Banta JA, Gifford ML, Fan AH, et al. Integration of responses within and across Arabidopsis natural accessions uncovers loci controlling root systems architecture. Proc Natl Acad Sci. 2013;110:15133-8. https://doi.org/10.1073/pnas.1305883110.

7. Rosas U, Barton NH, Copsey L, Barbier de Reuille P, Coen E. Cryptic variation between species and the basis of hybrid performance. PLoS Biol. 2010;8:e1000429. https://doi.org/10.1371/journal.pbio.1000429.

8. Berger BA, Ricigliano VA, Savriama Y, Lim A, Thompson V, Howarth DG. Geometric morphometrics reveals shifts in flower shape symmetry and size following gene knockdown of CYCLOIDEA and ANTHOCYANIDIN SYNTHASE. BMC Plant Biol. 2017;17:205. https://doi.org/10.1186/ s12870-017-1152-X.

9. Rosas-Reinhold I, Piñeyro-Nelson A, Rosas U, Arias U. Blurring the boundaries between a branch and flower: potential developmental venues in Cactaceae. Plants. 2021;10(6):1134. https://doi.org/10.3390/plants1006 1134.

10. Mauseth JD. Structure-function relationships in highly modified shoots of cactaceae. Ann Bot. 2006;98:901-26. https://doi.org/10.1093/aob/mcl133.

11. Bravo-Hollis H. Las cactáceas de México - Tomo I. 2nd ed. Mexico: Instituto de Biología, UNAM; 1978.

12. Arias S, Guzmán-López L, Guzmán-Cruz U, Vázquez-Benítez B. Cactaceae. Flora del Valle de Tehuacán-Cuicatlán. Fascículo 95. 1st ed. Mexico: Instituto de Biología, Universidad Nacional Autónoma de México; 2012. 
http://www.ibiologia.unam.mx/barra/publicaciones/floras_tehuacan/ F95.pdf

13. Cervantes RC, Hinojosa-Alvarez S, Wegier A, Rosas U, Arias S. Evaluating the monophyly of Mammillaria series Supertextae (Cactaceae). PhytoKeys. 177:25-42 In press.

14. Hunt D. A new review of Mammillaria names A-C. Bradleya. 1983;1983:105-28. https://doi.org/10.25223/brad.n1.1983.a10.

15. Guzmán U, Arias S, Dávila P. Catálogo de Cactáceas Mexicanas. 1st ed. Mexico: UNAM-CONABIO; 2003.

16. González-Sánchez JJ, Santiago-Sandoval I, Lara-González JA, ColchadoLópez J, Cervantes CR, Vélez P, et al. Growth patterns in seedling roots of the pincushion cactus Mammillaria reveal trends of intra- and interspecific variation. Front Plant Sci. 2021. https://doi.org/10.3389/fpls.2021. 750623.

17. Glover BJ, Martin C. The role of petal cell shape and pigmentation in pollination success in Antirrhinum majus. Heredity (Edinb). 1998;80:778-84. https://doi.org/10.1046/j.1365-2540.1998.00345.x.

18. de Almeida OJG, Sartori-Paoli AA, de Souza LA. Flower morpho-anatomy in Epiphyllum phyllanthus (Cactaceae). Rev Mex Biodivers. https://www. biodiversitylibrary.org/part/111950.

19. Koski MH, Galloway LF. Geographic variation in floral color and reflectance correlates with temperature and colonization history. Front Plant Sci. 2020;11:991. https://doi.org/10.3389/fpls.2020.00991.

20. Martins C, Oliveira R, Aguiar LMS, Antonini Y. Pollination biology of the endangered columnar cactus Cipocereus crassisepalus: a case of close relationship between plant and pollinator. Acta Bot Bras. 2020;34:177-84 http://www.scielo.br/scielo.php?script=sci_arttext\&pid=S0102-33062 $020000100177 \& \mathrm{nrm}=\mathrm{iso}$.

21. Ferreira BH d S, Souza CS, Fachardo ALS, Gomes AC, Sigrist MR. Flowering and pollination ecology of Cleistocactus baumannii (Cactaceae) in the Brazilian Chaco: pollinator dependence and floral larceny. Acta Bot Bras. 2020;34:167-76 http://www.scielo.br/scielo.php?script=sci_arttext\&pid= S0102-33062020000100167\&nrm=iso.

22. Martínez-Peralta C, Martínez-Zavala A. Flower biology of the cactus Coryphantha elephantidens in the tropical dry forest of Central Mexico. Plant Species Biol. 2021;36:102-13. https://doi.org/10.1111/1442-1984.12303.

23. Guerrero PC, Majure LC, Cornejo-Romero A, Hernández-Hernández T. Phylogenetic relationships and evolutionary trends in the Cactus family. J Hered. 2018;110:4-21. https://doi.org/10.1093/jhered/esy064.

24. Mosco A. Tissue localization of betacyanins in cactus stems. Rev Mex Biodivers. 2012;83:413-20 http://www.scielo.org.mx/scielo.php?script= sci_arttext\&pid=S1870-34532012000200012\&nrm=iso.

25. Whibley AC, Langlade NB, Andalo C, Hanna Al, Bangham A, Thébaud C, et al. Evolutionary paths underlying flower color variation in antirrhinum. Science. 2006;313:963-6.

26. Langlade NB, Feng X, Dransfield T, Copsey L, Hanna Al, Thébaud C, et al. Evolution through genetically controlled allometry space. Proc Natl Acad Sci. 2005;102:10221-6. https://doi.org/10.1073/pnas.0504210102.

27. R Core Team. R. A language and environment for statistical computing; 2019. http://www.r-project.org/index.html

28. Group WB. Solar resource data obtained from the global solar atlas, owned by the World Bank Group and provided by Solargis; 2019.

\section{Publisher's Note}

Springer Nature remains neutral with regard to jurisdictional claims in published maps and institutional affiliations.

Ready to submit your research? Choose BMC and benefit from:

- fast, convenient online submission

- thorough peer review by experienced researchers in your field

- rapid publication on acceptance

- support for research data, including large and complex data types

- gold Open Access which fosters wider collaboration and increased citations

- maximum visibility for your research: over $100 \mathrm{M}$ website views per year

At BMC, research is always in progress.

Learn more biomedcentral.com/submissions 